Arq. Bras. Med. Vet. Zootec., v.67, n.2, p.465-473, 2015

\title{
Effect of body development from first insemination to first weaning on performance and culling until the third farrowing of Landrace $x$ Large White swine females
}

[Efeito do desenvolvimento corporal desde a primeira inseminação até o primeiro desmame no desempenho e descarte até o terceiro parto de fêmeas suínas Landrace $x$ Large White]

\author{
P.E. Lesskiu, M.L. Bernardi, I. Wentz, F.P. Bortolozzo*
}

Universidade Federal do Rio Grande do Sul - UFRGS - Porto Alegre, RS

\begin{abstract}
The aim of this study was to verify the association of sow body weight development until the $1^{\text {st }}$ weaning with reproductive performance, piglet production and culling rate until the $3^{\text {rd }}$ farrowing in 196 primiparous sows using logistic regression models. Each $10 \mathrm{~kg}$ increase in weight gain in the $1^{\text {st }}$ pregnancy $(\mathrm{OR}=0.63)$, weight at $1^{\text {st }}$ farrowing $(\mathrm{OR}=0.70)$, weight at the $1^{\text {st }}$ weaning $(\mathrm{OR}=0.73)$ or weight gain from the $1^{\text {st }}$ artificial insemination $(\mathrm{AI})$ to the $1^{\text {st }}$ weaning $(\mathrm{OR}=0.67)$ decreased the percentage of primiparous sows with long weaning-to-oestrus interval - WOI ( $>5$ days). An increasing lactation length and an increase in the number of weaned piglets were responsible for respectively decreasing $(\mathrm{OR}=0.77-0.80$, per day of lactation) and increasing $(\mathrm{OR}=1.52-1.59$, per piglet weaned $)$ the percentage of sows with long WOI. Sows with $<159.5 \mathrm{~kg}$ at weaning had higher odds of non-farrowing (NFR) compared to sows with $>170 \mathrm{~kg}(\mathrm{OR}=4.73)$. Sows with $<17.5 \mathrm{~kg}$ of gain from the $1^{\text {st }}$ AI to the $1^{\text {st }}$ weaning had higher odds $(\mathrm{OR}=4.88)$ of NFR than sows gaining $>30 \mathrm{~kg}$. Each additional lactation day decreased the NFR $(\mathrm{OR}=0.74)$. Females weighing $<139 \mathrm{~kg}$ at the $1^{\text {st }} \mathrm{AI}$ had higher percentages of small numbers of total born in the second parity $(\mathrm{STB} 2, \mathrm{OR}=2.00)$ and over three parities $(\mathrm{OR}=3.28)$ compared to those weighing $\geq 139 \mathrm{~kg}$. Sows with weight gain $<25 \mathrm{~kg}$ at the $1^{\text {st }}$ pregnancy had higher odds of STB2 $(\mathrm{OR}=3.01)$ compared to sows gaining $>35 \mathrm{~kg}$. Each $10 \mathrm{~kg}$ of increase in weight at the $1^{\text {st }}$ weaning or in weight gain from the $1^{\text {st }}$ AI to the $1^{\text {st }}$ weaning decreased the total culling rate $(\mathrm{OR}=0.71$ and 0.73 , respectively) and culling for reproductive reasons $(\mathrm{OR}=0.57$ and 0.61 , respectively). The culling rate until the $3^{\text {rd }}$ farrowing was also increased in sows with a smaller first litter size. The results show that not only reaching a minimum weight at the $1^{\text {st }} \mathrm{AI}$ but also having an adequate body weight gain until the $1^{\text {st }}$ weaning is important for the reproductive performance, productivity and retention of Landrace $\mathrm{x}$ Large White Danbred sows in the herd.
\end{abstract}

Keywords: Sows, body weight, litter size, reproductive performance, retention rate

\section{RESUMO}

O objetivo do estudo foi verificar, com modelos de regressão logística, a associação entre características de desenvolvimento corporal até o $1^{o}$ desmame com o desempenho reprodutivo, produção de leitões e taxa de remoção até o $3^{\circ}$ parto de 196 fêmeas suínas primíparas. Houve redução nas chances de as fêmeas terem intervalo desmame-estro (IDE) longo (>5 dias) a cada $10 \mathrm{~kg}$ de aumento no ganho de peso na $1^{a}$ gestação GPG1 (razão de chance $-R C=0,63)$, peso no $1^{\circ}$ parto $-P P 1(R C=0,70)$, peso no $1^{\circ}$ desmame $-P D 1(R C=$ $0,73)$ ou ganho de peso da $1^{a}$ inseminação artificial (IA) ao $1^{\circ}$ desmame - GPIAD1 (RC=0,67). O percentual de porcas com IDE longo reduziu com o aumento da duração da lactação $(R C=0,77-0,80$, por dia de lactação) e aumentou com o aumento no número de leitões desmamados $(R C=1,52-1,59$, por leitão desmamado). Porcas com $<159,5 \mathrm{~kg}$ ao desmame tiveram maior chance de não parir (NP) em comparação a porcas com $>170 \mathrm{~kg}(R C=4,73)$. Porcas com $<17,5 \mathrm{~kg}$ de GPIADl tiveram maior chance $(R C=4,88)$ de $N P$ do que porcas ganhando $>30 \mathrm{~kg}$. $O$ aumento da duração da lactação reduziu a chance de $N P(R C=0,74$, para cada dia). Fêmeas com $<139 \mathrm{~kg}$ na $1^{a}$ IA tiveram maior chance de terem leitegada pequena no segundo parto $\operatorname{LPSP}(R C=2,00)$ ou ao longo de 3 partos $(R C=3,28)$, em comparação às fêmeas com $\geq 139 \mathrm{~kg}$. Fêmeas com

Recebido em 17 de julho de 2013

Aceito em 30 de julho de 2014

*Autor para correspondência (corresponding author)

E-mail: fpbortol@ufrgs.br 
GPG1 <25kg tiveram maior chance de LPSP $(R C=3,01)$ do que fêmeas com $>35 \mathrm{~kg}$. Houve diminuição na taxa geral de descarte $(R C=0,71$ e 0,73, respectivamente) e descarte por causas reprodutivas $(R C=0,57 e$ 0,61, respectivamente) para cada $10 \mathrm{~kg}$ de aumento no PD1 e GPIAD1. A taxa de descarte até o $3^{\circ}$ parto também aumentou nas porcas com menor leitegada no primeiro parto. Os resultados mostram que, além de atingir um peso mínimo na $1^{a} I A$, o ganho de peso entre a $1^{a}$ IA e o primeiro desmame é importante para o desempenho reprodutivo, produtividade e retenção de fêmeas Danbred Landrace x Large White no rebanho.

Palavras-chave: porcas, peso corporal, tamanho da leitegada, desempenho reprodutivo, taxa de retenção

\section{INTRODUCTION}

Sow lifetime productivity is important to herd profitability. However, the premature culling of gilts and young sows results in more sows producing only 30 to 40 piglets per lifetime against the potential for 60 or more (Lucia et al., 2000; Engblom et al., 2007).

The high productivity of herds is influenced by a correct parity distribution, which starts with the management of replacement gilt, and female development up to the first pregnancy and lactation (Anil et al., 2006; Amaral Filha et al., 2010; Hoving et al., 2010; Schenkel et al., 2010). The age of first oestrus, body weight and average daily gain of gilts influence their subsequent reproductive performance (Roongsitthichai et al., 2013). The importance of a target weight of gilts at the $1^{\text {st }}$ mating and the $1^{\text {st }}$ farrowing has been reported by several authors (Clowes et al., 2003; Young et al., 2004; Kummer et al., 2006; Roongsitthichai et al., 2013).

The third or greater oestrus is recommended for the insemination of Landrace $\mathrm{x}$ Large White (Danbred) gilts, provided that they are older than $230 \mathrm{~d}$ and weigh at least $138 \mathrm{~kg}$ (Danbred, 2012). The third oestrus was also suggested to be the optimal to mate gilts, as it resulted in more piglets produced throughout their lifetime (Cottney et al., 2012). Although it has been observed that under commercial conditions some gilts reach the recommended breeding weight at an earlier age, little information is available taking into account body development in the first cycle of production, the weight target at $1^{\text {st }}$ farrowing and weaning, and their consequences on the lifetime performance and retention in the herd in Danbred females. The aim of this study was to verify the association of sow body weight development from first AI until first weaning with the reproductive performance, piglet production and culling rate until $3^{\text {rd }}$ farrowing in Landrace x Large White Danbred sows.

\section{MATERIALS AND METHODS}

The study was performed with 196 pregnant Landrace $(75 \%)$ x Large White $(25 \%)$ gilts $\left(\right.$ DB90 ${ }^{\circledast}$ - Danbred line) in a gilt development unit (GDU) and in a sow farm, both located in the Midwest of Santa Catarina state, Brazil. Puberty stimulation started when gilts were $159.2 \pm 0.41$ days of age. Gilts were inseminated on the second or third post pubertal oestrus, when they achieved the target weight $(\geq 135 \mathrm{~kg})$. They were mated on average at $210.3 \pm 11.6$ days of age and $140.4 \pm 6.6 \mathrm{~kg}$. At approximately 37 days of pregnancy, 10 to 12 pregnant gilts per week were moved to a sow farm (1000 heads capacity). Their performance was followed until they reached the $3^{\text {rd }}$ farrowing.

In GDU, gilts were penned in groups, with each one containing 12 gilts and a space allowance of $1.5 \mathrm{~m}^{2}$ per female. Gilts were fed $2.6 \mathrm{~kg} /$ day until two weeks before insemination with a standard corn soybean gestation diet $(3204 \mathrm{kcal} \mathrm{ME} / \mathrm{kg}$, $14.2 \% \mathrm{CP}$ and $0.64 \%$ lysine). Two weeks before AI, gilts were housed in crates $(0.55 \times 2.2 \mathrm{~m})$ where they were fed $3.5 \mathrm{~kg} / \mathrm{day}$ of the gestation diet. After AI gilts were automatically fed a gestation diet twice a day with the following schedule: between 0 and 5 days of gestation (day $0=$ day of first AI) females received $1.8 \mathrm{~kg} /$ day; from 6 to 85 days of gestation, 1.8, 2 or $2.2 \mathrm{~kg} /$ day was provided according to the body condition score of the sows (Young et al., 2004), and from 86 to 110 days they received 2.6 to $2.8 \mathrm{~kg} /$ day. After being transferred to farrowing crates, all sows were fed a corn soybean lactation diet $(3412 \mathrm{kcal} \mathrm{ME} / \mathrm{kg}, 18.6 \% \mathrm{CP}$ and $0.99 \%$ lysine) twice a day, with a gradual decrease in the amount provided, from 4 days before $(2.8 \mathrm{~kg})$ up to the predicted farrowing date $(1 \mathrm{~kg})$. After farrowing, sows were fed with increasing amounts of feed, from $1 \mathrm{~kg}$ on the first day up to $4 \mathrm{~kg}$ on third day. From the third day onwards they were fed ad libitum. After weaning, until they were bred, sows received $3 \mathrm{~kg}$ of the 
lactation diet, divided into three portions per day. Water supply was always provided ad libitum. Culling reasons were recorded and locomotor disorders, diseases (mastitis, MMA syndrome), small number of born piglets and reproductive failures were included. Reproductive failures included anoestrus after weaning, vulvar discharge, return to oestrus, abortion, and failure to farrow after positive pregnancy detection.

All statistical analyses were performed using the Statistical Analysis System software, version 9.1.3 (Statistical..., 2005). Descriptive statistics were generated by the UNIVARIATE procedure.

Logistic regression models, using the LOGISTIC procedure, were run to evaluate the effect of sow characteristics until first weaning on their reproductive performance and culling rate until third farrowing. Backward elimination was used to determine which factors could be excluded from each model based on a likelihood ratio Chisquare statistic corresponding to $\mathrm{P}=5 \%$ at each step. Six binary outcome dependent variables were studied: long weaning-to-oestrus interval (LWOI; yes $=>5$ days or no $=\leq 5$ days); nonfarrowing (yes/no); small number of total born piglets in second parity (STB2; yes $=<11$ piglets or no $=\geq 11$ piglets); small number of total born piglets over three parities (STB3P; yes $=<34$ piglets or no $=\geq 34$ piglets); total culling (yes/no), and culling by reproductive reasons (yes/no). Due to the low number of sows culled by locomotor (3 sows) or productive (3 sows) reasons, these culling reasons were not separately analysed. Litter size and WOI were investigated as binary outcome variables by separating sows in two classes so that approximately one quarter of them had the occurrence of the event being studied: $21.2 \%$, $27.1 \%$ and $28.4 \%$ of sows with LWOI, STB2 and STB3P, respectively. Only sows that farrowed without interruptions (return to oestrus, abortion or failure to farrow) were considered in the analysis of sows with STB2 or STB3P.

The following explanatory variables were tested: age at $1^{\text {st }} \mathrm{AI}$; weight at $1^{\text {st }} \mathrm{AI}$; oestrus at breeding (second or third oestrus); weight gain during $1^{\text {st }}$ pregnancy; weight at $1^{\text {st }}$ farrowing; weight loss during $1^{\text {st }}$ lactation; weight at $1^{\text {st }}$ weaning; weight gain from $1^{\text {st }}$ AI to $1^{\text {st }}$ weaning; total number of piglets born in the $1^{\text {st }}$ parity; number of piglets weaned in the $1^{\text {st }}$ parity, and lactation length in the $1^{\text {st }}$ parity. Explanatory variables were first analysed as continuous variables and when they were not significant they were introduced in the model as categorical variables. The following categories were created: age at $1^{\text {st }}$ AI $(\leq 210$ or $>210 \mathrm{~d}$ ); weight at $1^{\text {st }}$ AI ( $<139$ and $\left.\geq 139 \mathrm{~kg}\right)$; weight gain in the $1^{\text {st }}$ pregnancy $(<25 ; 25-35$ and $>35 \mathrm{~kg})$; weight at the $1^{\text {st }}$ farrowing $(<163.5$; $163.5-175$ and $>175 \mathrm{~kg})$; weight at $1^{\text {st }}$ weaning $(<159.5 ; 159.5-170$ and $>170 \mathrm{~kg})$; relative weight loss in the $1^{\text {st }}$ lactation $(<0.5 \% ; 0.5-7.4 \%$ and $>7.4 \%)$; weight gain from $1^{\text {st }}$ AI to $1^{\text {st }}$ weaning ( $<17.5 ; 17.5-30$ and $>30 \mathrm{~kg})$; lactation length in the $1^{\text {st }}$ parity $(<19 ; 19-20$ and $>20$ days $)$; number of piglets weaned in the $1^{\text {st }}$ parity $(10,11$ and $>11$ piglets), and total number of piglets born in the $1^{\text {st }}$ parity $(<12,12-13$ and $>13$ piglets). The categories concerning these variables were established to have approximately 50\% (two classes) or $33 \%$ (three classes) of sows in each class. The frequency distributions of sows for each dependent variable within explanatory categorical independent variables were obtained with the FREQ procedure.

Before running the logistic regression models, the possible colinearity among the variables was examined by correlation analysis with the CORR procedure. To avoid colinearity problems, independent variables with a Pearson correlation coefficient $>0.40$ were not simultaneously included in the multivariable models. From 10 independent variables, five were correlated with a correlation coefficient $>0.40$ and were tested separately. Thus, for each one of the dependent variables, five multivariable models were run (Table 1). Six independent variables were present in all models (age at $1^{\text {st }} \mathrm{AI}$, weight at $1^{\text {st }}$ AI, oestrus at breeding, total number of piglets born in $1^{\text {st }}$ parity, lactation length in $1^{\text {st }}$ parity, and number of piglets weaned in $1^{\text {st }}$ lactation), and one additional variable was added to the other six, in each tested model (weight gain during $1^{\text {st }}$ pregnancy, weight at $1^{\text {st }}$ farrowing, weight at $1^{\text {st }}$ weaning, weight loss during $1^{\text {st }}$ lactation or weight gain from $1^{\text {st }}$ AI to $1^{\text {st }}$ weaning). In all models the effects of the interaction between age and weight at $1^{\text {st }} \mathrm{AI}$ could also be investigated. 
Table 1. Variables tested in multivariable logistic regression to investigate their effect on long weaningto-oestrus interval, non-farrowing rate, small total number of born piglets in the second parity or over three parities, and on culling rate from $1^{\text {st }}$ to $3^{\text {rd }}$ farrowing

\begin{tabular}{lccccc}
\hline Independent variables & Model 1 & Model 2 & Model 3 & Model 4 & Model 5 \\
\hline Age at $1^{\text {st }}$ AI & $\mathrm{X}$ & $\mathrm{X}$ & $\mathrm{X}$ & $\mathrm{X}$ & $\mathrm{X}$ \\
Weight at $1^{\text {st }} \mathrm{AI}$ & $\mathrm{X}$ & $\mathrm{X}$ & $\mathrm{X}$ & $\mathrm{X}$ & $\mathrm{X}$ \\
Oestrus at breeding & $\mathrm{X}$ & $\mathrm{X}$ & $\mathrm{X}$ & $\mathrm{X}$ & $\mathrm{X}$ \\
Number of piglets in $1^{\text {st }}$ farrowing & $\mathrm{X}$ & $\mathrm{X}$ & $\mathrm{X}$ & $\mathrm{X}$ & $\mathrm{X}$ \\
Lactation length in $1^{\text {st }}$ parity & $\mathrm{X}$ & $\mathrm{X}$ & $\mathrm{X}$ & $\mathrm{X}$ & $\mathrm{X}$ \\
Weaned piglets in $1^{\text {st }}$ lactation & $\mathrm{X}$ & $\mathrm{X}$ & $\mathrm{X}$ & $\mathrm{X}$ & $\mathrm{X}$ \\
Weight gain in $1^{\text {st }}$ pregnancy & $\mathrm{X}$ & & & \\
Weight at $1^{\text {st }}$ farrowing & & $\mathrm{X}$ & $\mathrm{X}$ & $\mathrm{X}$ \\
Weight at $1^{\text {st }}$ weaning & & & $\mathrm{X}$ \\
Weight loss in $1^{\text {st }}$ lactation & & & \\
Weight gain $1^{\text {st }}$ AI to $1^{\text {st }}$ weaning & & & \\
\hline When variables were not significant as continuous they were tested as categorical.
\end{tabular}

When variables were not significant as continuous they were tested as categorical.

\section{RESULTS}

Sows weighed $170.8 \pm 16.0$ and $163.7 \pm 16.2 \mathrm{~kg}$ at $1^{\text {st }}$ farrowing and $1^{\text {st }}$ weaning, respectively, and gained $23.3 \pm 16.2 \mathrm{~kg}$ from $1^{\text {st }}$ AI to $1^{\text {st }}$ weaning. The number of total born piglets in the $1^{\text {st }}, 2^{\text {nd }}$ and $3^{\text {rd }}$ farrowing were $12.5 \pm 2.8,11.8 \pm 2.9$ and $12.2 \pm$ 3.1 , respectively. The first lactation lasted on average $19.9 \pm 2.2$ days and sows had $11.2 \pm 1.0$ weaned piglets. The $1^{\text {st }}$ and $2^{\text {nd }}$ weaning-to-oestrus intervals were of $5.7 \pm 5.4$ and $4.6 \pm 2.2$ days, respectively.
Factors associated with long WOI or non-farrowing are shown at Table 2. Each $10 \mathrm{~kg}$ of increase in weight gain in $1^{\text {st }}$ pregnancy, weight at $1^{\text {st }}$ farrowing, weight at weaning, and weight gain from $1^{\text {st }}$ AI to $1^{\text {st }}$ weaning reduced the risk for long WOI. An increase in the number of weaned piglets was responsible for increasing the percentage of sows with long WOI. An increasing lactation length decreased the occurrence of long WOI and nonfarrowing. Sows with $<159.5 \mathrm{~kg}$ at weaning had higher odds of non-farrowing compared to sows with $>170 \mathrm{~kg}$. Sows with $<17.5 \mathrm{~kg}$ of gain from $1^{\text {st }}$ AI to $1^{\text {st }}$ weaning had higher odds of non-farrowing than sows gaining $>30 \mathrm{~kg}$.

Table 2. Results of logistic regression analysis for variables associated with long weaning-to-oestrus interval (> 5 days) and non-farrowing after the first weaning

\begin{tabular}{|c|c|c|c|c|c|c|}
\hline Variables & Category & $\mathrm{n}$ & $\%$ Sows & Odds ratio & $95 \%$ CI & P-value \\
\hline \multicolumn{7}{|l|}{ Long weaning-to-oestrus interval } \\
\hline $\begin{array}{l}\text { Weight gain in the } 1^{\text {st }} \text { pregnancy } \\
\text { (per } 10 \mathrm{~kg} \text { ) }\end{array}$ & Continuous & 189 & 21.2 & 0.63 & $0.48-0.82$ & 0.0008 \\
\hline Weight at $1^{\mathrm{st}}$ farrowing (per $10 \mathrm{~kg}$ ) & Continuous & 189 & 21.2 & 0.70 & $0.54-0.90$ & 0.0054 \\
\hline Weight at $1^{\text {st }}$ weaning (per $10 \mathrm{~kg}$ ) & Continuous & 189 & 21.2 & 0.73 & $0.57-0.93$ & 0.0121 \\
\hline $\begin{array}{l}\text { Weight gain from the } 1^{\text {st }} \text { AI to } 1^{\text {st }} \\
\text { weaning (per } 10 \mathrm{~kg} \text { ) }\end{array}$ & Continuous & 189 & 21.2 & 0.67 & $0.52-0.87$ & 0.0022 \\
\hline $1^{\text {st }}$ lactation length (per d) $)^{\epsilon}$ & Continuous & 189 & 21.2 & $0.77-0.80$ & $0.65-0.96$ & 0.0190 \\
\hline $\begin{array}{l}\text { Number of weaned piglets (per } \\
\text { piglet weaned) }\end{array}$ & Continuous & 189 & 21.2 & $1.52-1.59$ & $1.04-2.30$ & 0.0291 \\
\hline \multicolumn{7}{|l|}{ Non-farrowing } \\
\hline \multirow[t]{3}{*}{ Weight at $1^{\text {st }}$ weaning, $\mathrm{kg}$} & $<159.5$ & 59 & 13.6 & 4.73 & $0.94-23.67$ & 0.051 \\
\hline & $159.5-170.0$ & 67 & 3.0 & 0.72 & $0.09-5.61$ & 0.7579 \\
\hline & $>170.0$ & 63 & 3.2 & Ref & NA & NA \\
\hline Weight gain from the $1^{\text {st }} \mathrm{AI}$ to & $<17.5$ & 56 & 12.5 & 4.88 & $0.96-24.89$ & 0.0565 \\
\hline \multirow[t]{2}{*}{$1^{\text {st }}$ weaning, $\mathrm{kg}$} & $17.5-30.0$ & 66 & 4.5 & 1.28 & $0.20-8.34$ & 0.7948 \\
\hline & $>30.0$ & 67 & 3.0 & Ref & NA & NA \\
\hline $1^{\text {st }}$ lactation length (per d) & Continuous & 189 & 6.3 & 0.74 & $0.57-0.96$ & 0.0260 \\
\hline
\end{tabular}

CI: confidence interval; NA = not applicable.

${ }^{\epsilon}$ Minimum and maximum values for OR and CI are derived from multivariable models in which lactation length and number of weaned piglets were significant. 
Low weight at the $1^{\text {st }}$ insemination and low number of total born piglets in the $1^{\text {st }}$ farrowing were associated with the occurrence of small litter sizes in both second parity and over three parities (Table 3). Sows with weight gain $<25 \mathrm{~kg}$ in the $1^{\text {st }}$ pregnancy had higher odds of STB2 compared to sows gaining $>35 \mathrm{~kg}$. Lower percentages of sows with STB2 were observed in those having a weight loss $\geq 0.5 \%$ compared to those with a weight loss $<0.5 \%$.

Table 3. Results of logistic regression analysis for variables associated with small total number of born piglets in the second parity (STB2: <11 piglets) or over three parities (STB3P: <34 piglets)

\begin{tabular}{|c|c|c|c|c|c|c|}
\hline Variable & Category & $\mathrm{n}$ & $\%$ Sows $^{\Omega}$ & Odds ratio & $95 \% \mathrm{CI}$ & P-value \\
\hline $\begin{array}{l}\text { Sows with STB2 } \\
\text { Weight at } 1^{\text {st }} \text { AI, kg }\end{array}$ & $\begin{array}{l}<139 \\
\geq 139\end{array}$ & $\begin{array}{l}89 \\
88\end{array}$ & $\begin{array}{l}32.6 \\
21.6\end{array}$ & $\begin{array}{l}2.00 \\
\text { Ref }\end{array}$ & $\begin{array}{l}0.97-4.09 \\
\text { NA }\end{array}$ & $\begin{array}{l}0.0508 \\
\text { NA }\end{array}$ \\
\hline $\begin{array}{l}\text { Total born piglets in } \\
\text { the } 1^{\text {st }} \text { farrowing }\end{array}$ & $\begin{array}{l}<12 \\
12-13 \\
>13\end{array}$ & $\begin{array}{l}52 \\
59 \\
66\end{array}$ & $\begin{array}{l}40.4 \\
22.0 \\
21.2\end{array}$ & $\begin{array}{c}2.70-2.98 \\
0.95-1.06 \\
\text { Ref }\end{array}$ & $\begin{array}{c}1.17-6.99 \\
0.39-2.54 \\
\text { NA }\end{array}$ & $\begin{array}{c}0.0203 \\
0.9180 \\
\text { NA }\end{array}$ \\
\hline $\begin{array}{l}\text { Weight gain in the } 1^{\text {st }} \\
\text { pregnancy, } \mathrm{kg}\end{array}$ & $\begin{array}{c}<25 \\
25-35 \\
>35\end{array}$ & $\begin{array}{l}54 \\
62 \\
61\end{array}$ & $\begin{array}{l}37.0 \\
25.8 \\
19.7\end{array}$ & $\begin{array}{l}3.01 \\
1.44 \\
\text { Ref }\end{array}$ & $\begin{array}{l}1.24-7.32 \\
0.60-3.48 \\
\text { NA }\end{array}$ & $\begin{array}{c}0.0149 \\
0.4108 \\
\text { NA }\end{array}$ \\
\hline $\begin{array}{l}\text { Weight loss } \\
\text { in the } 1^{\text {st }} \text { lactation, } \%\end{array}$ & $\begin{array}{l}>7.4 \\
7.4-0.5 \\
<0.5\end{array}$ & $\begin{array}{l}58 \\
60 \\
59\end{array}$ & $\begin{array}{l}19.0 \\
21.7 \\
40.7\end{array}$ & $\begin{array}{l}0.29 \\
0.32 \\
\text { Ref }\end{array}$ & $\begin{array}{l}0.12-0.69 \\
0.14-0.76 \\
\text { NA }\end{array}$ & $\begin{array}{c}0.0052 \\
0.0096 \\
\text { NA }\end{array}$ \\
\hline $\begin{array}{l}\text { Sows with STB3P } \\
\text { Weight at } 1^{\text {st }} \text { AI, kg }\end{array}$ & $\begin{array}{l}<139 \\
\geq 139\end{array}$ & $\begin{array}{l}79 \\
76\end{array}$ & $\begin{array}{l}39.2 \\
17.1\end{array}$ & $\begin{array}{l}3.28 \\
\text { Ref }\end{array}$ & $\begin{array}{l}1.41-7.66 \\
\text { NA }\end{array}$ & $\begin{array}{l}0.0060 \\
\text { NA }\end{array}$ \\
\hline $\begin{array}{l}\text { Total born piglets in the } 1^{\text {st }} \\
\text { farrowing }\end{array}$ & Continuous & 155 & 28.4 & 0.66 & $0.55-0.78$ & $<0.0001$ \\
\hline
\end{tabular}

CI: confidence interval; NA $=$ not applicable.

For both STB2 and STB3P, only sows that reached the $2^{\text {nd }}$ and $3^{\text {rd }}$ farrowing, respectively, without any interruption (return to oestrus, abortion or failure to farrow) were considered for the analysis.

${ }^{\Omega}$ Percentage of sows with small litter size at $2^{\text {nd }}$ farrowing (STB2) or over three parities (STB3P).

${ }^{€}$ Minimum and maximum values for OR and CI are derived from multivariable models in which the number of total born in the $1^{\text {st }}$ farrowing was significant.

Each $10 \mathrm{~kg}$ of increase in weight at the $1^{\text {st }}$ weaning or in weight gain from the $1^{\text {st }} \mathrm{AI}$ to the $1^{\text {st }}$ weaning (Table 4$)$ decreased $(\mathrm{P}<0.05)$ the total culling rate and culling by reproductive reasons. Sows with $<12$ piglets in the $1^{\text {st }}$ parity increased the probability of culling until the $3^{\text {rd }}$ farrowing compared to sows which farrowed $>13$ piglets in the $1^{\text {st }}$ parity.

\section{DISCUSSION}

The average weight of $140 \mathrm{~kg}$ observed at approximately 210 days of age shows that some gilts reached the recommended weight for the first breeding before 230-260 days of age, which is considered the target age to obtain a good productivity (Rathje and Himmelberg, 2004; Danbred, 2012). In order to have a higher number of total piglets born in Danbred gilts, the sows should be exposed to mature boars at approximately 200 days of age and be bred when they weigh at least 136-138kg (Ketchem and Rix, 2009; Danbred, 2012). In the present study, the performance of Landrace $x$ Large White Danbred gilts was not compromised even when they were bred at $\leq 210$ days of age, showing that they can be bred at an earlier age than previously recommended provided that they reach at least approximately $140 \mathrm{~kg}$. In another genotype (Camborough C22), the farrowing rate, culling rate and piglets produced over three parities also was not affected when gilts were inseminated between 185 and 209 days of age compared to those inseminated at $\geq 210$ days of age (Kummer et al., 2006). 
Table 4. Results of multivariable logistic regression analysis for variables associated with total culling or culling by reproductive reasons until the third farrowing

\begin{tabular}{|c|c|c|c|c|c|c|}
\hline Variable & Category & $\mathrm{n}$ & $\begin{array}{c}\% \\
\text { Culling }\end{array}$ & $\begin{array}{l}\text { Odds } \\
\text { ratio }\end{array}$ & $95 \% \mathrm{CI}$ & P-value \\
\hline $\begin{array}{l}\text { Total culling } \\
\text { Weight at } 1^{\mathrm{st}} \text { weaning } \\
\text { (per } 10 \mathrm{~kg})\end{array}$ & Continuous & 196 & 10.2 & 0.71 & $0.54-0.93$ & 0.0133 \\
\hline $\begin{array}{l}\text { Weight gain from the } 1^{\text {st }} \text { AI to the } \\
1^{\text {st }} \text { weaning (per } 10 \mathrm{~kg} \text { ) }\end{array}$ & Continuous & 196 & 10.2 & 0.73 & $0.55-0.95$ & 0.0218 \\
\hline $\begin{array}{l}\text { Number of total born in the } 1^{\text {st }} \\
\text { farrowing }\end{array}$ & $\begin{array}{l}<12 \\
12-13 \\
>13\end{array}$ & $\begin{array}{l}61 \\
62 \\
73\end{array}$ & $\begin{array}{l}18.0 \\
4.8 \\
8.2\end{array}$ & $\begin{array}{l}2.46 \\
0.57 \\
\text { Ref }\end{array}$ & $\begin{array}{l}0.85-7.09 \\
0.14-2.37 \\
\text { NA }\end{array}$ & $\begin{array}{c}0.0167 \\
0.1187 \\
\text { NA }\end{array}$ \\
\hline $\begin{array}{l}\text { Culling by reproductive reasons } \\
\text { Weight at } 1^{\text {st }} \text { weaning } \\
\text { (per } 10 \mathrm{~kg} \text { ) }\end{array}$ & Continuous & 196 & 4.1 & 0.57 & $0.38-0.85$ & 0.0053 \\
\hline $\begin{array}{l}\text { Weight gain from the } 1^{\text {st }} \text { AI to the } \\
1^{\text {st }} \text { weaning (per } 10 \mathrm{~kg} \text { ) }\end{array}$ & Continuous & 196 & 4.1 & 0.61 & $0.41-0.90$ & 0.0119 \\
\hline $\begin{array}{l}\text { Number of total born in the } 1^{\text {st }} \\
\text { farrowing }\end{array}$ & $\begin{array}{l}<12 \\
12-13 \\
>13\end{array}$ & $\begin{array}{l}61 \\
62 \\
73\end{array}$ & $\begin{array}{l}9.8 \\
1.6 \\
1.4 \\
\end{array}$ & $\begin{array}{l}7.85 \\
1.18 \\
\text { Ref }\end{array}$ & $\begin{array}{l}0.92-67.1 \\
0.07-19.3 \\
\text { NA }\end{array}$ & $\begin{array}{l}0.0174 \\
0.4510 \\
\text { NA }\end{array}$ \\
\hline
\end{tabular}

CI: confidence interval; NA = not applicable.

The following reasons were included in the total culling: locomotor disorders, diseases (mastite, MMA syndrome), small number of born piglets and reproductive failures. Reproductive reasons included anoestrus after weaning, vulvar discharge, return to oestrus, abortion, and failure to farrow.

Weight at first mating can have a significant effect on lifetime performance, and females with an insufficient development when first selected and introduced into the farm generally fail to achieve a reasonable number of parities (Close and Cole, 2001; Foxcroft et al., 2004). Longevity is also influenced by gilt growth, compositional and structural soundness traits (Nikkilä et al., 2013). Even though gilts were bred weighing $\geq 135 \mathrm{~kg}$, those with a weight of $>139 \mathrm{~kg}$ produced more piglets over three parities, highlighting the importance of an adequate weight at first mating for females of the genotype used in the present study. However, the average maternal weight gain during first pregnancy $(30.3 \pm 1.13 \mathrm{~kg})$ was below the range of $40-50 \mathrm{~kg}$, which is considered ideal for young females (Close and Cole, 2001; Young et al., 2005). The fact that longer WOI was associated to lower maternal weight gain, and that a weight gain below $25 \mathrm{~kg}$ during first pregnancy increased the number of sows with a smaller second litter size shows that even when the minimum weight at the $1^{\text {st }}$ mating is reached it is essential to have an adequate weight gain during the first pregnancy.
The importance of adequate body reserves at first farrowing and weaning for a successful reproductive performance has been well documented in females of other genotypes (Mullan and Williams, 1989; Clowes et al., 2003; Schenkel et al., 2010). For the variables studied, weight at $1^{\text {st }}$ weaning was found to be more important than weight at first farrowing. Hoving et al. (2010) showed that production in the second parity can be optimised if growth between the $1^{\text {st }} \mathrm{AI}$ and the $1^{\text {st }}$ weaning is increased. In the present study, the weight gain until the first weaning was important to shorten the weaning-to-oestrus interval, to increase the farrowing rate and to reduce the culling rate until the $3^{\text {rd }}$ parity.

Although it is well documented that high lactational catabolism can affect WOI (Zak et al., 1997; Yang et al., 2000), this was not observed in the present study, confirming that this variable can be less sensitive to body reserve losses in modern genotypes (Vinsky et al., 2006; Schenkel et al., 2010). On the other hand, modern genotypes can have embryonic survival (Vinsky et al., 2006) or piglet production in the second farrowing (Schenkel et al., 2010) compromised 
by body reserve depletion during lactation. In the present study, the paradoxical higher risk of smaller second litters in sows that lost less weight during the $1^{\text {st }}$ lactation $(<0.5 \%)$ is probably explained by the fact that they were not able to overcome the detrimental effect of a reduced weight gain during the $1^{\text {st }}$ pregnancy $(22 \mathrm{~kg})$ and $/$ or a reduced weight achieved at first farrowing $(162 \mathrm{~kg})$ in contrast with the values of 38 and $179 \mathrm{~kg}$ observed in sows that lost more weight during lactation.

A short WOI is important for the lifetime performance because primiparous sows mated within 5 days after weaning have higher farrowing rate and more piglets produced than females with longer WOI (Tantasuparuk et al., 2001; Poleze et al., 2006). The occurrence of shorter WOI in primiparous sows as the lactation increases is in agreement with other studies (Willis et al., 2003; Poleze et al., 2006; Soede et al., 2009), in which the WOI was consistently short when the lactation length was beyond 20 days. In the present study, a longer lactation length was also important to reduce the percentage of non-farrowing sows, corroborating the positive effect of an increasing lactation length on lifetime performance (Rathje and Himmelberg, 2004). A short lactation length has a negative effect on post-weaning follicular development and subsequent interval to oestrus, ovulation response and even farrowing rate and litter size (Soede et al., 2009). Furthermore, reproductive failures have been related to a short lactation length as a consequence of incomplete uterine involution (Le Cozler et al., 1997; Takai and Koketsu, 2007). The increase in the percentage of sows with longer WOI as the number of weaned piglets increased is probably related to the inhibition of hypothalamicpituitary axis activity (Cox and Britt, 1982) which can lead to a later resumption of follicular development and return to oestrus (Quesnel et al., 2007).

Lifetime piglet production is one of the criteria used to decide if a sow remains in the herd or not. The association of litter size in the $1^{\text {st }}$ farrowing with piglet production in subsequent farrowings (Hoving et al., 2010) was confirmed in the present study, explaining the higher culling rate observed in sows with $<12$ piglets born in the $1^{\text {st }}$ farrowing. The culling rate until the $3^{\text {rd }}$ farrowing was also affected by the weight at $1^{\text {st }}$ weaning and the weight gain from the $1^{\text {st }} \mathrm{AI}$ and the $1^{\text {st }}$ weaning, because these characteristics were associated with reproductive disorders (long WOI and non-farrowing at parity 2), which had been reported as factors contributing to low retention of sows in herds (Zak et al., 1997; Lucia et al., 2000; Tantasuparuk et al., 2001; Roongsitthichai et al., 2013).

\section{CONCLUSIONS}

The variables concerning weight development from the $1^{\text {st }}$ mating until $1^{\text {st }}$ weaning affect the lifetime reproductive performance and the retention of Landrace $\mathrm{x}$ Large White Danbred sows in the herd, showing that if a minimum threshold is not achieved, in several phases of development until mature size, growth might be prioritised above reproduction. The weight gain between the $1^{\text {st }}$ AI to the $1^{\text {st }}$ weaning is the variable that best summarises the importance of adequate body reserves because it includes body reserve changes occurring during both pregnancy and lactation.

\section{REFERENCES}

AMARAL FILHA, W.; BERNARDI, M.L.; WENTZ, I.; BORTOLOZZO, F.P. Reproductive performance of gilts according to growth rate and backfat thickness at mating. Anim. Reprod. Sci., v.121, p.139-144, 2010.

ANIL, S.S.; ANIL, L.; DEEN, J. et al. Association of inadequate feed intake during lactation with removal of sows from the breeding herd. J. Swine Health Prod., v.14, p.296-301, 2006.

CLOSE, W.H.; COLE, D.J.A. Practical feeding strategies. In: CLOSE, W.H.; COLE, D.J.A. (Eds). Nutrition of sows and boars. 1.ed. Nottingham: Nottingham University Press, 2001. p.293-331.

CLOWES, E.J.; AHERNE, F.X.; SCHAEFER, A.L. et al. Parturition body size and body protein loss during lactation influence performance during lactation and ovarian function at weaning in first-parity sows. J. Anim. Sci., v.81, p.15171528, 2003. 
COTTNEY, P.D.; MAGOWAN, E.; BALL, M.E.E.; GORDON, A. Effect of oestrus number of nulliparous sows at first service on first litter and lifetime performance. Livest. Sci., v.146, p.512, 2012.

COX, N.M.; BRITT, J.H. Pulsatile administration of gonadotropin releasing hormone to lactating sows: endocrine changes associated with induction of fertile estrus. Biol. Reprod., v.27, p.1126-1137, 1982.

DANBRED. Guia de Manejo de Fêmeas DBDanbred. Management guide to DB-Danbred females. 2.ed, 2012. 46p.

ENGBLOM, L.; LUNDEHEIM, N.; DALIN, A.; ANDERSSON, K. Sow removal in Swedish commercial herds. Livest. Sci., v.106, p.76-86, 2007.

FOXCROFT G.; PATTERSON J.; BELTRANENA E.; PETTITT, M. Identifying the true value of effective replacement gilt. In: MANITOBA SWINE SEMINAR, 18., 2004, Manitoba, Canadá. Proceedings ... Manitoba. 2004. p.3551.

HOVING, L.L.; SOEDE, N.M.; GRAAT, E.A.M. et al. Effect of live weight development and reproduction in first parity on reproductive performance of second parity sows. Anim. Reprod. Sci., v.122, p.82-89, 2010.

KETCHEM, R.; RIX, M. Are you reaching the potential for total pigs born? The Danbred Edge, v.4, p.3, 2009. Available at: $<$ http://www.danbredna.com/pdfs/December200 9.pdf>. Accessed in January 5, 2012.

KUMMER, R.; BERNARDI, M.L.; WENTZ, I.; BORTOLOZZO, F.P. Reproductive performance of high growth rate gilts inseminated at an early age. Anim. Reprod. Sci., v.96, p.47-53, 2006.

LE COZLER, Y.; DAGORN, J.; DOURMAD, J.Y. et al. Effect of weaning-to-conception interval and lactation length on subsequent litter size in sows. Livest. Prod. Sci., v.51, p.1-11, 1997.

LUCIA, Jr. T.; DIAL, G.D.; MARSH, W.E. Lifetime reproductive performance in female swine having distinct reasons for removal. Livest. Prod. Sci., v.63, p.213-222, 2000.
MULLAN, B.P.; WILLIAMS, I.H. The effect of body reserves at farrowing on the reproductive performance of first-litter sows. Anim. Prod., v.48, p.449-457. 1989.

NIKKILÄ, M.T.; STALDER, K.J.; MOTE, B.E. et al. Genetic associations for gilt growth, compositional, and structural soundness traits with sow longevity and lifetime reproductive performance. J. Anim. Sci., v.91, p.1570-1579. 2013.

POLEZE, E.; BERNARDI, M.L.; AMARAL FILHA, W.S. et al. Consequences of variation in weaning-to-estrus interval on reproductive performance of swine females. Livest. Sci., v.103, p.124-130, 2006.

QUESNEL, H.; ETIENNE, M.; PÈRE, M.C. Influence of litter size on metabolic status and reproductive axis in primiparous sows. J. Anim. Sci., v.85, p.118-128. 2007.

RATHJE, T.; HIMMELBERG, L. Emerging technologies in reproduction: How the Danes have reached $30 \mathrm{pigs} / \mathrm{sow} / \mathrm{year}$. In: American Association of Swine Veterinarians (AASV). Proceedings... 2004. p.395-398.

ROONGSITTHICHAI, A.; CHEUCHUCHART, P.; CHATWIJITKUL, S. et al. Influence of age at first estrus, body weight, and average daily gain of replacement gilts on their subsequent reproductive performance as sows. Livest. Sci., v.151, p.238-245. 2013.

STATISTICAL Analysis System - SAS Institute Inc., SAS/STAT software. Version 9.1.3, Cary, NC: SAS Institute Inc. 2005.

SCHENKEL, A.C.; BERNARDI, M.L.; BORTOLOZZO, F.P.; WENTZ, I. Body reserve mobilization during lactation in first parity sows and its effect on second litter size. Livest. Sci., v.132, p.165-172, 2010.

SOEDE, N.M.; HAZELEGER, W.; GERRITSEN, R. et al. Ovarian responses to lactation management strategies. Soc. Reprod. Fertil., v.66, p.177-186, 2009.

TAKAI, Y.; KOKETSU, Y. Identification of a female-pig profile associated with lower productivity on commercial farms. Theriogenology, v.68, p.87-92, 2007. 
TANTASUPARUK, W.; LUNDEHEIM， N.; DALIN, A.M. et al. Weaning-to-service interval in primiparous sows and its relationship with longevity and piglet production. Livest. Prod. Sci., v.69, p.155-162, 2001.

VINSKY, M.; NOVAK, S.; DYCK, M. et al. Nutritional restriction in lactating primiparous sows selectively affects female embryo survival and overall litter development. Reprod. Fert. Dev., v.18, p.347-355, 2006.

WILLIS, H.J.; ZAK, L.J.; FOXCROFT, G.R. Duration of lactation, endocrine and metabolic state, and fertility of primiparous sows. J. Anim. Sci., v.81, p.2088-2102, 2003.

YANG, H.; FOXCROFT, G.R.; PETTIGREW, J.E. et al. Impact of dietary lysine intake during lactation on follicular development and oocyte maturation after weaning in primiparous sows. $J$. Anim. Sci., v.78, p.993-1000, 2000.
YOUNG, M.G.; TOKACH, M.D.; AHERNE, F.X. et al. Comparison of three methods of feeding sows in gestation and the subsequent effects on lactation performance. J. Anim. Sci., v.82, p.3058-3070, 2004.

YOUNG, M.G.; TOKACH, M.D.; AHERNE, F.X. et al. Effect of sow parity and weight at service on target maternal weight and energy for gain in gestation. J. Anim. Sci., v.83, p.255-261, 2005.

ZAK, L.J.; COSGROVE, J.R.; AHERNE, F.X.; FOXCROFT, G.R. Pattern of feed intake, and associated metabolic and endocrine changes, differentially affect post-weaning fertility in the primiparous sow. J. Anim. Sci., v.75, p.208-216, 1997. 